\title{
Effects of a Nano-structured Surface Layer on Titanium Implants for Osteoblast Proliferation Activity
}

\section{Árpád Joób-Fancsaly ${ }^{1}$, Albert Karacs², Gábor Petö², Kinga Körmöczi $^{1}$, Sándor Bogdán ${ }^{1}$, Tamás Huszár ${ }^{1}$}

${ }^{1}$ Semmelweis University, Department of Oral and Maxillofacial Surgery, Mária u. 52, H-1085 Budapest, Hungary

${ }^{2}$ Research Institute for Technical Physics and Materials Science, Hungarian Academy of Sciences, P.O. Box 49, H-1525 Budapest, Hungary

E-mail: joob_fancsaly.arpad@dent.semmelweis-univ.hu

\begin{abstract}
The goal of this study is to compare surface morphologies on dental implants created by a range of five different surface-modification technologies and, in addition, cell assays to assess the subsequent cell proliferation on each treated surface. In our research, we surface-treated 5 mm-diameter - 2 mm-thick discs, machined from Grade 1 titanium. We treated the surfaces of the discs with chemical etching, electro-polishing, $\mathrm{Al}_{2} \mathrm{O}_{3}$ sandblasting, and surface melting with 1 Joule or 3 Joule impulse-energy laser beam. We carried out quantitative as well as qualitative analyses with stereo and scanning electron microscopes (SEM), confocal and atomic force microscopes (AFM) and goniometer. We examined each surface with cell-testing, as a measure of osseointegration. In tests with fibroblasts, the highest cell proliferation occurred on the $\mathrm{Al}_{2} \mathrm{O}_{3}$-roughened surfaces. In the case of osteoblasts, we measured the greatest cell activity on the laser-melted samples with different energy levels.
\end{abstract}

Keywords: surface modification; surface analyses; surface morphology; cell proliferation

\section{Introduction}

Currently the examination and deliberate structuring of surface morphologies of dental implants, designing new processes for surface manipulation and the assessment of those results, are all at the cutting edge of implantology. Surface treatment of implants influences, to a major extent, the success of integration with bone [1], making these processes crucial to the functional value of implants. To ensure this integration, a suitable morphology must be created on the surface of a given implant [2]. 


\subsection{Conditions for Osseointegration}

Thirty years ago researchers considered how surface engineering, topography, and the morphology or lack of contamination of implant surface, might affect osseointegration. Since that time, investigators have made substantial progress in making issues of surface shape and contamination central to dental implantology research. In the early 1970s, development has sought to: understand the interaction between the bone and the implant surface, explain the process of osseointegration from the moment of implantation until the phase when secondary stability is attained, and define both the duration of, and the biological mechanisms involved in, each phase $[3,4,5,6]$.

Exact phases of the development of the interface zone are still unknown. The interface layer ensures a connection between the oxide layer on the implant surface and bone proteins. The layer around the osseointegrated implant has a

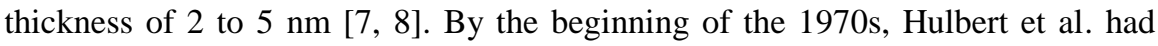
already established that porous surfaces enable bone regeneration to occur more quickly and allow osseous tissue to grow [9]. The consensus since the year 2000 has been that rough surfaces are better for osseointegration than smooth or polished surfaces [10-15].

Molecular biology has gradually gained significance in surface treatment. Researchers are developing increasingly sophisticated surface-engineering techniques that take into account biochemical signals and cues involved in how various materials bond with bone tissue. The possibility of applying organic materials (chemical modifications) and several proteins (BMP) on an implants surface, creates new areas of investigation [16]. The interaction of proteins at the nanometric level is emerging as a major decider in the integration of implants.

Up until the end of the 1990s, investigations mostly addressed surface topography and morphology. Since then, attention has increasingly focused on surfacechemistry research. Surfaces are modified with physical-chemical methods to promote faster and more comprehensive osseointegration. High surface energy optimally promotes interaction with the biological environment [17-19]. It is accepted that surface roughness influences alkaline phosphatase (ALP) and osteocalcin (OC) levels, thus indicating the osteoblast activity of the surrounding tissues $[20,21]$. On a smooth surface, "osteoblast-like" cells show a sparse and flat distribution, while greater numbers and more dense distributions are found on rough surfaces [22, 23]. Rough surfaces have an impact on cytoskeleton functions as well [24]. Micro-scale surface structures influence cellular functions while nano-scale elements have an effect on sophisticated cascades involved in protein binding (Figure 1) [25-27]. 


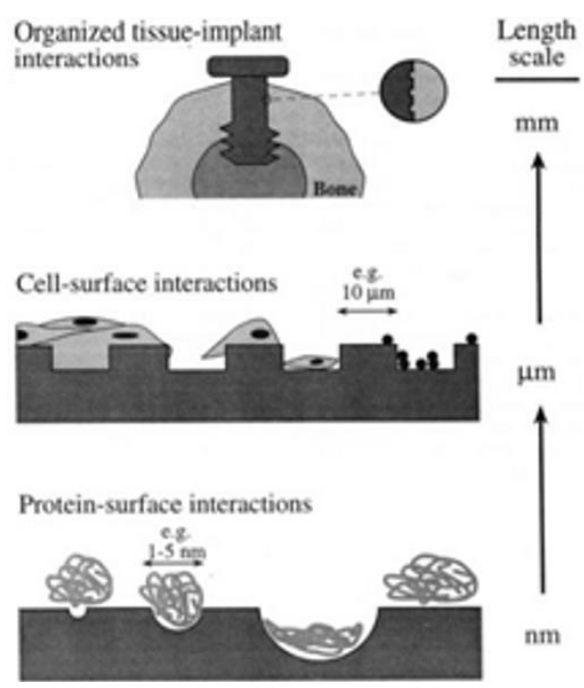

Figure 1

The effect of surfaces with various degrees of structure on the binding of organic elements

According to the current status of the science for osseointegration, it is not a function of quantitative porosity but qualitative porosity [28]. In the case of dental implants the most commonly used and at least accepted parameters are the following: the average height differences of elements raised above the surface, usually represented as "Sa" (in the case of a two-dimensional examination the same value is signified by "Ra"), effectively the average of the wave-lengths (distances), which is named "Scx", and finally the sum of treated and untreated surfaces, which is called Sdr and is described as a "hybrid" value. According to Wennerber and colleagues as well as most of the research community, what can be described as ideal surface parameters are $\mathrm{Sa}=1.4 \mu \mathrm{m}, \mathrm{Scx}=11.6 \mu \mathrm{m}$, $\mathrm{Sdr}=1.5 \mu \mathrm{m}$ [29-33]. On the basis of the literature a surface can be viewed as rough when the hybrid value is $>2 \mu \mathrm{m}$. It is medium rough if that given value falls between $1 \mu \mathrm{m}$ and $2 \mu \mathrm{m}$, and smooth, or at least mildly rough if $<1 \mu \mathrm{m}$ [34]. Wennerberg and colleagues showed with animal experiments the $1.5 \mu \mathrm{m}$ hybrid value is the most favorable and associated with cases of the greatest osseointegration [35]. Lazzara and colleagues showed this and Ivanov was doing human experiments supported with results involving human volunteer subjects $[36,37]$.

It's possible to characterize the quality of a surface with bone-implant contact (BIC) values, which show what percentage of an implant surface comes into direct contact with bone. After decalcification, with a histology-morphology examination of a tissue slice it is possible to tabulate the percentage ratio of boneimplant connection (BIC) [38]. For sufficient bone integration the lower jaw BIC average is $40.7 \%$, while in the case of the upper jaw this average is only $37.2 \%$ [39]. 
The percentage ratio of bone-implant contact is not easy to calculate. Results recorded as obtained in various journals in the literature vary widely across a very broad scale. They depend on the species of experimental animal, the type of bone the implant was attached to (femur, tibia, jaw), the healing time, and the surface treatment applied to the implant.

Hansson devised a mathematical model describing interdependences between the measure of osseointegration and the surface roughness of an implant. Surfaces of commercially obtainable implants serve as the basis of the model. He established that hollows of depth $1.5 \mu \mathrm{m}$ and diameter of 3 to $5 \mu \mathrm{m}$ in the implant surface are advantageous for integration with bone [40].

\subsection{Surface-Modification Methods}

Current machining methods give dental implants unique geometries. Leading manufacturers most often create implants with diameters from 1 to $4.2 \mathrm{~mm}$ and lengths from 2 to $14 \mathrm{~mm}$ [41]. The geometric structure and surface-preparation of implants plays a central role in primary and secondary stabilization [42]. The most common methods for modifying surface morphology are chemical etching [4345], sand-blasting [46], these two in combination [47], grit blasting [48], surface melting by laser [49], and anodic oxidation [50, 51].

A freshly machined surface is often used as a reference in experiments for mutual comparison. Literature discussing machined surfaces describes massive bone formation around the implants, which results in a stable connection between implant and bone tissue [52]. Anomalies on the machined surface go to a depth of $5 \mu \mathrm{m}$ in profile. On the surface at a spacing of 5-8 $\mu \mathrm{m}$, slightly unevenly arranged but roughly parallel grooves can be observed. The separation and depth of the grooves was equal. With the help of a profileometer the three most characteristic pieces of data were $\mathrm{Sa}=0.836 \mu \mathrm{m}, \mathrm{Scx}=8.38 \mu \mathrm{m}$ and $\mathrm{Sdr}=1.3 \mu \mathrm{m}$ [35]. In the literature there are reports of quite wide intervals (between grooves) on the machined surface with $\mathrm{Ra}$, in the range $0.08-4.7 \mu \mathrm{m}$ [53].

The BIC ranges between 39 and $47 \%$ according to Ericsson and colleagues, as opposed to around 50\% according to Wennerbeg et al. [54, 55]. In animalexperiment studies the value has been observed at $62 \%$ after 3 months [56]. One drawback is that in several places the surface is contaminated by noticeable machining fragments.

On the basis of the profilometer studies by Wennerberg et al $(\mathrm{Sa}=1.9 \mu \mathrm{m}$; $\operatorname{Scx}=12.3 \mu \mathrm{m} ; \mathrm{Sdr}=1.42 \mu \mathrm{m})$ the parameters of the acid-treated surface closely approach the supposedly ideal values [35]. The results of animal studies support this, showing a BIC value of $88 \%$ after three months of healing [56]. According to Baker et al. animal experiments in the case of acid-treated surfaces bone adhesion starts earlier than with other treated surfaces [57]. Human trials carried out by Trisi and colleagues showed that in case of acid-treated surfaces the BIC 
percentage value resembles that of freshly-machined surfaces [58]. They regard the payoff from this method to be the chance to load the implant early on. The other big benefit in each acid-treating process is a high level of surface cleanliness, in that the acid removes the outermost layer of the surface.

In the case of sand-blasting the surface can be blasted with particles of different sizes $(25,75,250 \mu \mathrm{m})$. With animal studies Wennerberg and colleagues showed that smaller particles resulted better osseointegration than larger, and suggested using $75 \mu \mathrm{m}$ sized granules. According to data obtained with the help of an optical profilometer, granules of the size of $25 \mu \mathrm{m}$ produced a surface characterized by Sa values $=1.13 \mu \mathrm{m} ; \mathrm{Scx}=9.78 \mu \mathrm{m}$; and $\mathrm{Sdr}=1.39 \mu \mathrm{m}$, while the surface produced by $75 \mu \mathrm{m}$ particle blasting has the following values $\mathrm{Sa}=1.38 \mu \mathrm{m}$; $\mathrm{Scx}=11.62$ $\mu \mathrm{m} ; \mathrm{Sdr}=1.47 \mu \mathrm{m}$ (although they approach the ideal parameters very closely). In the case of the $250 \mu \mathrm{m}$ particles the values were $\mathrm{Sa}=2.15 \mu \mathrm{m} ; \mathrm{Scx}=13.54 \mu \mathrm{m}$; $\mathrm{Sdr}=1.79 \mu \mathrm{m}$. The BIC was $62 / 62 \%$ (the mandible/maxilla ratio). During animalexperiment studies this value rose after 3 months to $71 \%$ [14, 35, 56, 59]. The disadvantage of the process is that the material used for the sand-blasting can contaminate the surface, and because of this the chemical features of the implant can be unacceptable.

Buser et al examined surface treatments of the titanium used as dental-implant base material. The samples were treated with chemical etching, electro-polishing, or coated with hydroxyapatite. They established that surfaces treated with chemical etching and hydoxyapatite underwent more bone-integration than the samples with electro-polished surfaces [60].

The development of nanotechnology, analyzing the possibilities of implants with nanostructured surfaces, is at the center of numerous current research-anddevelopment projects. Christenson and colleagues looked at organized nanostructures falling into the 1 to $100 \mathrm{~nm}$ size range. The "nano" expression can cover crystal structures of material, extracted or built out from the surface layer [61].

Carlos et al completed studies on surface treatments to dental implants made of Grade 4 titanium. They changed the surface morphology with sand-blasting, chemical etching, and anodic oxidation. They prepared SEM images of the surface and then established the level of surface roughness with confocal microscopy. They tested each surface for wettability with contact angle measurements. The surface-modified implants were inserted into live rat tibias and then after 12 weeks removed. They established that chemical etching created a homogeneous surface. Surfaces treated with anodic oxidation measured the lowest while at the same time those implants had the highest screw-out force values [62].

Luiz's research group demonstrated the surface modification and testing possibilities of titanium as a raw material for dental implants. In their work they compared surfaces modified by mechanical polishing, electro-polishing, nanohydroxyapatite, and sprinkling with titanium dioxide and fluoride granules. With 
an atomic force microscope, a SEM and an X-ray photoelectron spectroscope the surface structures of the samples were tested. Experiments carried out on rats (time period: 4 weeks) measured the differently surface-treated implants with pullout tests. It was observed that implants coated with hydroxyapatite and modified with fluoride had better osseointegration than polished-surface implants. They established that in the several weeks after insertion the nanostructure assisted osseointegration [63].

In the research work of Vinzenz usable surface-treatment techniques for titanium implants are demonstrated. Furthermore he discusses several coating techniques, giving special attention to anodic plasma-chemical treatment of surfaces. Using scanning electron microscopy, X-ray spectroscopy, Raman spectroscopy, and laser-surface-roughness measurements he examined surfaces created by coating. With the results of cell and animal-experimentation examinations he showed that from the point of view of osseointegration the anodic plasma-chemical treated surface performed better than when untreated [64].

Research by Göransson introduces several surface-treatment and examination possibilities for dental implants made of titanium. In the experimental work samples with surfaces modified in 12 different ways were examined. He tested measures of osseointegration using cell experiments, animal experiment models, and human experiments. His result was that the surface structure did not significantly influence osseointegration and further that bioactive coatings also failed to produce significant results aiding improved osseointegration [65].

\subsection{Methods of Examining the Surface}

\subsubsection{In Vitro Methods}

It's usual to categorize methods of examination on the basis of which properties of surface morphology are tested by which method. This creates the primary division into chemical methods of analysis (X-ray Photoelectron Spectroscopy, Auger Electron Spectroscopy, Secondary Ion Mass Spectroscopy) and physical methods of analysis (Atomic Force Microscopy, Scanning Electron Microscopy).

\subsubsection{In Vivo Methods}

An often-used method for quantitative evaluation of the bone-implant contact's load-bearing capacity and the effects of the implant's geometrical characteristics (disregarding some unusual biological and chemical consequences of bone integration) is the pull-out test $[66,67]$. After the appropriate healing time has elapsed (in the literature 6 weeks, or else 3 or 6 months) with the help of a special instrument the already bone-embedded implant is removed from the bone and the torque necessary to do this is recorded [68, 69]. Values shown by the instrument can be checked against an already-derived table of standard results to obtain a $\mathrm{Ncm}$ value. Removal torque is a very widely used method for animal studies. 
In addition to studying implant morphology and with the above progress in mind, we decided to investigate how the nanostructure surface influences the proliferation of osteoblasts. Micro- and nano-morphological analyses revealed some correlations, including the potential biological, biochemical and physiological effects of surface roughness on bone cells adjacent to the implants. In these experiments titanium Grade 1 material was used.

\section{Materials and Methods}

For these experiments titanium Grade 1 (ISO5832 Pt.2 Grade I.) supplied thanks to the PROTETIM ${ }^{\circledR}$ company was made use of, machined discs of diameter $5 \mathrm{~mm}$ and thickness $2 \mathrm{~mm}$. The surfaces of the discs were first cleaned with ultrasonic equipment in pure ethanol. The chemical modification of the surfaces of the discs chemical treatment involved passivation in sodium-hydroxide $+\mathrm{H}_{2} \mathrm{O}_{2}$, oxalic acid, nitric acid solution, electropolishing, sandblasting was performed with $\mathrm{Al}_{2} \mathrm{O}_{3}$ particles of $250 \mu \mathrm{m}$, along with laser modification (Pulsed Nd/Yag laser (Kvant 1) with a $1 \mathrm{~J} /$ pulse as the low-pulse energy laser, and the $3 \mathrm{~J} /$ pulse was used for surface treating as high-pulse energy laser). In these experiments, the surfacetreated samples were compared with the machined discs as reference standards.

The machined surfaces of the discs were examined and images taken before their various treatments, first with a stereomicroscope (type: Olympus SZX 16), then with a scanning electron microscope (type: Philips XL 30). The discs' surface roughness values were compared quantitatively and qualitatively using a confocal microscope (type: Alicona Infinite Focus). Microscopic measures of the discs' nanostructures were taken (type: Veeco ${ }^{\circledR}$ diInnova ${ }^{\mathrm{TM}}$ ). Comparisons were carried out to measure contact angles and therefore hydrophilic or hydrophobic characteristics of the surfaces of the discs (equipment type: Rame-hart). The measurements were taken at $23^{\circ} \mathrm{C}$ temperature and $50 \%$ humidity. The device released 5-5 droplets $(5 \mu \mathrm{l} / \mathrm{droplet})$. The tests all used distilled water. Following the drop test (by 5 seconds) images were taken and the contact angles were measured using image-analysis software.

\subsection{Experiments Done with Cells}

Before the cell test the discs were placed for 20 minutes into tripsin solution, and for 20 minutes in alcohol, then sterilized in an autoclave. In twenty-four dishes, variously treated discs had NIH3T3 fibroblast and MC3T3 osteoblast cells added to their surfaces. For two days these cells were cultured on the disc surfaces in a cell-culturing medium (DMEM $+10 \%$ FBS). At the end of the incubation period discs with identical surface treatments are divided up into separate groups. 


\subsection{Cell-Counting}

Cells dissolved from the disc surfaces in tripsin solution were counted using a Bürker camera. After cell-counting, cells were dissolved in a low-temperature $200 \mu$ Triton (30 mM HEPES, $100 \mathrm{mM} \mathrm{NaCl}, 1 \mathrm{mM}$ EGTA, $20 \mathrm{mM} \mathrm{NaF}, 1 \%$ Triton X-100, $1 \mathrm{mM}$ PMSF, $20 \mu \mathrm{l} / \mathrm{ml}$ protease inhibitory cocktail, $1 \mathrm{mM} \mathrm{Na} \mathrm{VO}_{4}$ ) and then with the help of a spectrometer by the Bradford method, the concentration of dissolved protein (Bio-Rad Laboratories) was measured. Cellcounting was completed with a CyQuant DNA proliferation test. After culturing for two weeks CyQuant dye was added to the cells, coloring the DNA of each cell. After 5 minutes incubation the quantity of DNA was read off with a plate reader. Table 1 below lists the surface-treatment types and test methods used.

Table 1

Surface treatments and testing possibilities for Grade 1 titanium

\begin{tabular}{|c|c|c|}
\hline Type of surface treatment & Tests & Results \\
\hline Machined & \multirow{6}{*}{$\begin{array}{l}\text { - stereomicroscope } \\
\text { - scanning electron microscope } \\
\text { - confocal microscope } \\
\text { - contact-angle measurement } \\
\text { - cell testing (MC3T3) }\end{array}$} & \multirow{6}{*}{$\begin{array}{l}\text { - surface morphology } \\
\text { - surface roughness } \\
\text { - wettability } \\
\text { - cell-proliferation }\end{array}$} \\
\hline Machined + chemical etched & & \\
\hline Machined + electro-polished & & \\
\hline Machined + sandblasted $\left(\mathrm{Al}_{2} \mathrm{O}_{3}\right)$ & & \\
\hline $\begin{array}{l}\text { Machined + } 1 \text { Joule impulse-energy } \\
\text { laser surface modified }\end{array}$ & & \\
\hline $\begin{array}{l}\text { Machined + } 3 \text { Joule impulse-energy } \\
\text { laser surface modified }\end{array}$ & & \\
\hline
\end{tabular}

\section{Results}

In the illustrations below stereomicroscope images of samples are shown (Fig. 2).
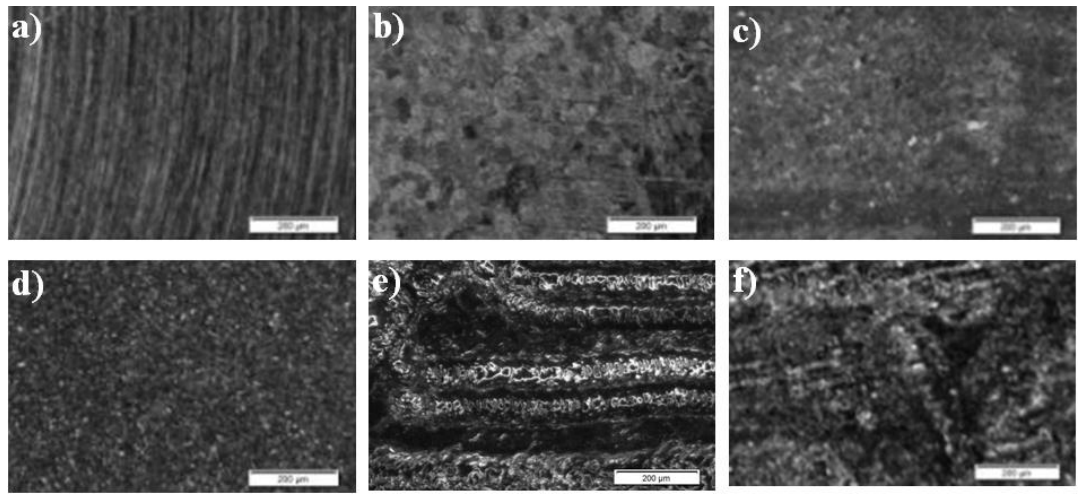

Figure 2

Stereo-microscope images of titanium disks machined (a), chemical etched (b), electro-polished (c), $\mathrm{Al}_{2} \mathrm{O}_{3}$ sandblasted (d), $1 \mathrm{~J}$ laser surface modified (e), and $3 \mathrm{~J}$ laser surface modified 
Machined: 3-10 $\mu \mathrm{m}$ width concentric grooves, running parallel to each other, irregular microgrooves. The depth and spacing of the furrows mostly regular. At numerous places on the surface contamination and machine-turning residue observable.

Machined + chemical etched: 1-3 $\mu \mathrm{m}$ width regularly arranged grooves. The primary leaf-form in the grooves run parallel to each other, but with grooves in the adjacent formations nearly perpendicular. This indicates that the groove patterning is not due to the original machining, but is caused by the subsequent surface modification. The leaf-shaped primary structure, about 20 to $25 \mu \mathrm{m}$ in diameter, is the basic unit of the surface.

Machined + electro-polished: smooth surface, although some traces of grooving from the machined surface are still visible.

Machined + sandblasted $\left(\mathrm{Al}_{2} \mathrm{O}_{3}\right)$ : irregularly-shaped, sharp-contoured raised areas, showing similar geometric depths.

Machined + surface modified with 1 Joule impulse energy laser: 50-70 $\mu$ m width grooves, regular waves on the surface. The surface is regular and smooth, insofar as microgrooving is smoothed down.

Machined + surface modified with 3 Joule impulse energy laser: 20-50 $\mu$ m width furrows and 10-20 $\mu \mathrm{m}$ diameter droplets. An orderly spaced, wave like primary structure can be observed with a distance of 30-60 $\mu \mathrm{m}$ from each other. The wave crest projections show 30 to $50 \mu \mathrm{m}$. The so-called secondary structure is pear shaped having a size of $10-15 \mu \mathrm{m}$.

On the SEM images 3-10 $\mu \mathrm{m}$ width grooves can be seen on the surface of the machined sample (Figure 3).
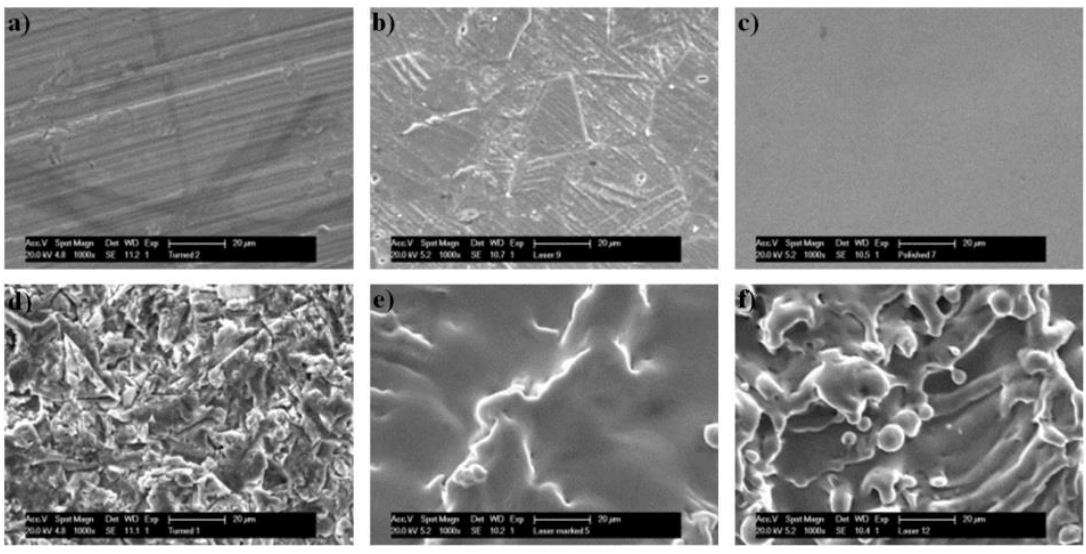

Figure 3

Scanning electron microscope images (magnification 1000×) machined (a), chemical etched (b), electropolished (c), $\mathrm{Al}_{2} \mathrm{O}_{3}$ sandblasted (d), $1 \mathrm{~J}$ laser surface modified (e), and $3 \mathrm{~J}$ laser surface modified 
After chemical etching there were ordered structure on the surface of the disk, parallel - though oriented in the original direction of the surface machining grooves separated by intervals of about 1-3 $\mu \mathrm{m}$. After electropolishing, a smooth uniform surface - absent the concentric grooving seen on the freshly machined samples - was apparent. The surface bombarded with $\mathrm{Al}_{2} \mathrm{O}_{3}$ sandblasting shows irregular roughly granular zones. The effect of 1 Joule impulse energy laser surface modification is $50-70 \mu \mathrm{m}$ wide, regular, wave-like grooving. Whereas 3 Joule impulse energy laser surface modification has the effect of creating 20-50 $\mu \mathrm{m}$ width grooves on the surface, in which solidified droplets of diameter 10-20 $\mu \mathrm{m}$ are visible.

With a confocal microscope of 3-3 measurements the average surface roughness (Ra) was established. Measurements were taken at $1500 \mu \mathrm{m}$ intervals. The different surface morphologies were compared in this case with the machined sample as a reference. The results of these measurements are brought together in Figure 4 below.

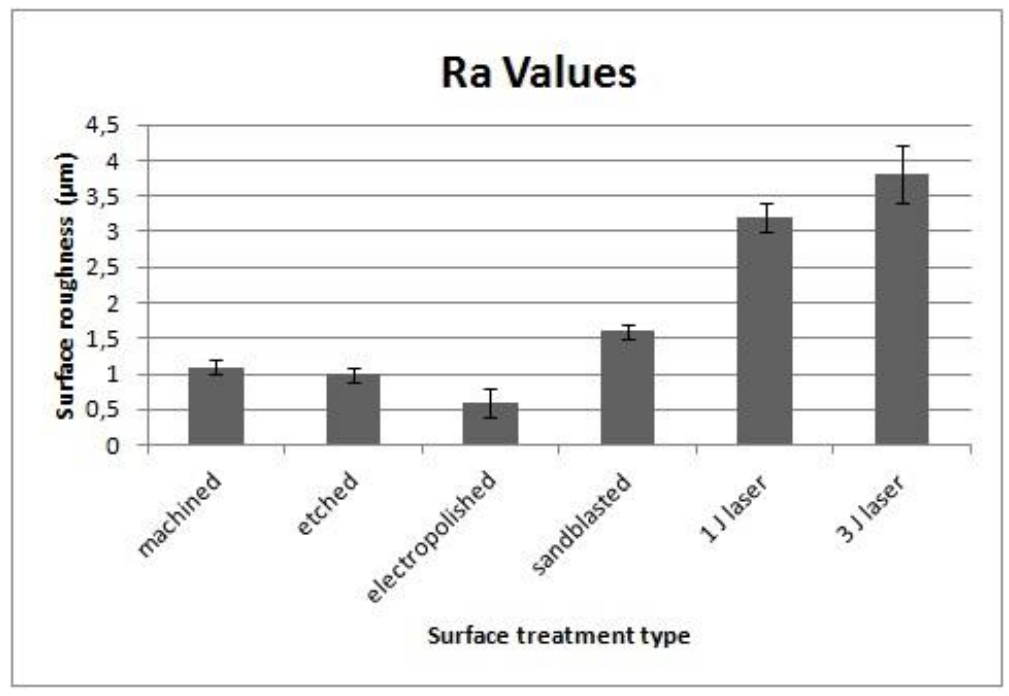

Figure 4

Measured values for the surface roughness $(\mathrm{Ra})$ of the discs

The surface roughness of the sample treated with electropolishing was the lowest $(\mathrm{Ra}=0.6 \pm 0.2 \mu \mathrm{m})$, while the highest value $(\mathrm{Ra}=3.8 \pm 0.4 \mu \mathrm{m})$ was for the discs treated with 3 Joule impulse laser modification. The chemically etched discs' surface roughness $(\mathrm{Ra}=1.0 \pm 0.1 \mu \mathrm{m})$ was slightly less than that of the freshly machined sample $(\mathrm{Ra}=1.1 \pm 0.1 \mu \mathrm{m})$. The titanium discs sandblasted with $\mathrm{Al}_{2} \mathrm{O}_{3}$ particles had a roughness of $\mathrm{Ra}=1.6 \pm 0.1 \mu \mathrm{m}$. The 1 Joule impulse energy laser modified surface had a roughness level $(\mathrm{Ra}=3.2 \pm 0.2 \mu \mathrm{m})$ only slightly less than that created by the 3 Joule laser. 
In the case of the measurements by the atomic-force microscope the measured surface was $400 \mu \mathrm{m}^{2}$. The results of the measurements are collected together in Figure 5 below.

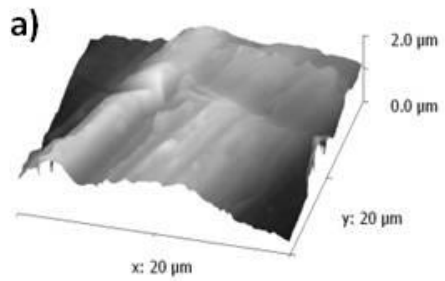

c)

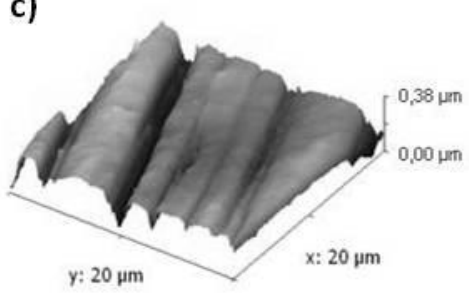

b)

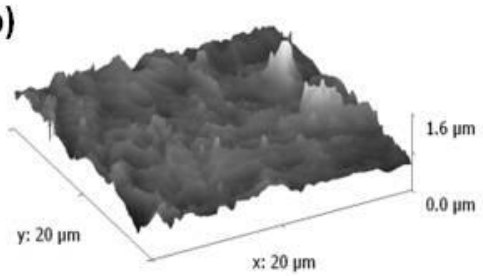

d)

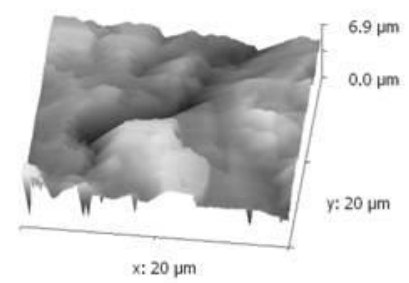

Figure 5

Titanium Grade 1 discs measurement results: machined (a), etched (b), electropolished (c), $\mathrm{Al}_{2} \mathrm{O}_{3}$ sandblasted (d)

The Ra roughness value for various treatments to the surface of the disc was as follows: machined $0.62 \mu \mathrm{m}$; chemically etched $0.08 \mu \mathrm{m}$; electropolished $0.04 \mu \mathrm{m}$; $\mathrm{Al}_{2} \mathrm{O}_{3}$ sandblasting $0.27 \mu \mathrm{m}$. Samples treated with laser surface-modification did not get subjected to AFM measurements. This is accounted for by physical limitations on the measurement method (extremely large Ra surface roughness, which goes beyond the measurement capacity of the instruments - NB: both the AFM and confocal microscope use methods which establish surface roughness values, but there are variations in the results which deviate from the surfaces examined). On the basis of the AFM measurements it was established that the value of surface roughness Ra was lowest for the electropolished discs and highest for the machined samples.

Contact angles were established, with the $\mathrm{Al}_{2} \mathrm{O}_{3}$ sandblasting $\left(60 \pm 10^{\circ}\right)$ and 1 Joule impulse energy laser surface modification $\left(51 \pm 3^{\circ}\right)$ results close together within margins of error. The electropolished sample surface had the lowest value $\left(27 \pm 4^{\circ}\right)$, while the 3 Joule impulse energy laser treatment gave the highest contact-angle values $\left(102 \pm 4^{\circ}\right)$.

The following quantitative and qualitative characteristics were subjected to cell testing. 


\subsection{Cell-Counting and Protein Concentration Measurement}

Results of cell-counting and protein concentration in both the fibroblast and the osteoblast cases showed increased cell proliferation on the roughened surfaces when compared with the machined surface. Tables 2 and 3 present the measured results as averages \pm standard deviation. Numbers in the columns are relative values which show what the cell count or protein concentration was on the given surface to the value for the machined surface - used widely in the literature as the reference surface.

Table 2

Changes of cell numbers and protein concentration of NIH3T3 fibroblast cells measured on various modified surfaces compared to the group with a machined surface

\begin{tabular}{l}
\multicolumn{1}{c}{ Sample } \\
\hline Machined \\
Machined + chemical etched \\
Machined + electropolished \\
Machined + sandblasted $\left(\mathrm{Al}_{2} \mathrm{O}_{3}\right)$ \\
\hline $\begin{array}{l}\text { Machined + 1 Joule impulse energy laser } \\
\text { surface modified }\end{array}$ \\
Machined + 3 Joule impulse energy laser \\
surface modified
\end{tabular}

\begin{tabular}{|c|c|}
\hline Cell number & Prot. Conc. \\
\hline 1 & 1 \\
\hline $1.85 \pm 0.15$ & $1.34 \pm 0.28$ \\
\hline $3.24 \pm 0.12$ & $2.53 \pm 0.35$ \\
\hline $5.19 \pm 0.59$ & $3.18 \pm 0.41$ \\
\hline $3.17 \pm 0.33$ & $2.66 \pm 0.26$ \\
\hline $2.83 \pm 0.36$ & $2.31 \pm 0.15$ \\
\hline
\end{tabular}

Table 3

Changes of cell numbers and protein concentration of MC3T3 osteoblast cells measured on various modified surfaces compared to the group with a machined surface

\begin{tabular}{|l|c|c|}
\hline \multicolumn{1}{|c|}{ Sample } & Cell number & Prot. Conc. \\
\hline Machined & 1 & 1 \\
\hline $\begin{array}{l}\text { Machined + chemical etching } \\
\text { Machined + electropolished }\end{array}$ & $1.55 \pm 0.16$ & $1.40 \pm 0.21$ \\
\hline $\begin{array}{l}\text { Machined + sandblasted }\left(\mathrm{Al}_{2} \mathrm{O}_{3}\right) \\
\begin{array}{l}\text { Machined + 1 Joule impulse energy laser } \\
\text { surface modification }\end{array}\end{array}$ & $3.15 \pm 0.32$ & $2.32 \pm 0.41$ \\
\hline $\begin{array}{l}\text { Machined + 3 Joule impulse energy laser } \\
\text { surface modification }\end{array}$ & $3.83 \pm 0.25 \pm 0.33$ & $3.05 \pm 0.45$ \\
\hline
\end{tabular}

\section{Conclusions}

In the experiments $5 \mathrm{~mm}$ diameter, $2 \mathrm{~mm}$ thickness discs machined from Grade 1 titanium were used. The chemical treatment to the surface of the discs involved passivation in sodium-hydroxide $+\mathrm{H}_{2} \mathrm{O}_{2}$, oxalic acid, nitric acid solution, electropolishing, $\mathrm{Al}_{2} \mathrm{O}_{3}$ sandblasting, as well as laser pulse surface modification (Pulsed Nd/Yag laser (Kvant 1) with a $1 \mathrm{~J} /$ pulse is the low pulse energy laser, and 
the $3 \mathrm{~J} /$ pulse was used for surface treating as high pulse energy laser). Images were taken of the discs using a stereomicroscope and a scanning electron microscope. On the scanning electron microscope images 3-10 $\mu \mathrm{m}$ width grooving can be seen on the freshly-machined sample surfaces.

After chemical etching, structures appear on the surface of the discs parallel to each other - but these follow the orientation of the structures on the machined surface, $1-3 \mu \mathrm{m}$ grooves.

After electropolishing we obtain a smooth surface, without the concentric grooves visible on the machined samples.

The $\mathrm{Al}_{2} \mathrm{O}_{3}$ sandblasted surfaces showed irregular, roughly granular zones. The effect of the 1 Joule impulse energy laser surface modification was 50-70 $\mu \mathrm{m}$ width, regular, wave-shaped surface grooving. Whereas the effect of 3 Joule impulse energy laser surface modification was to create $20-50 \mu \mathrm{m}$ width grooves on the surface, in which solidified droplets of diameter 10-20 $\mu \mathrm{m}$ were visible.

During examination with a confocal microscope, it was established that the surface roughness value of the electropolished samples $(\mathrm{Ra}=0.6 \pm 0.2 \mu \mathrm{m})$ was the lowest, while the highest roughness values $(\mathrm{Ra}=3.8 \pm 0.4 \mu \mathrm{m})$ were produced on 3 Joule impulse energy laser modified discs. The roughness value for those discs treated with chemically etching $(\mathrm{Ra}=1.0 \pm 0.1 \mu \mathrm{m})$ was slightly less than that for the freshly machined samples. The surface roughness of the titanium discs treated with $\mathrm{Al}_{2} \mathrm{O}_{3}$ sandblasting was $\mathrm{Ra}=1.6 \pm 0.1 \mu \mathrm{m}$. Roughness values for discs surface-modified by the 1 Joule pulsed energy laser $(\mathrm{Ra}=3.2 \pm 0.2 \mu \mathrm{m})$ deviated only slightly from the 3 Joule laser value.

AFM measurements of the samples were carried out. The machined discs had surface roughness values of $0.62 \mu \mathrm{m}$, the chemically etched $0.08 \mu \mathrm{m}$, the electropolished $0.04 \mu \mathrm{m}$, the $\mathrm{Al}_{2} \mathrm{O}_{3}$ sandblasted samples $0.27 \mu \mathrm{m}$. It was not possible to take accurate AFM measurements of the laser surface modified surfaces.

Contact angles were established for wetting of the $\mathrm{Al}_{2} \mathrm{O}_{3}$ sandblasted surfaces $\left(60 \pm 10^{\circ}\right)$, the 1 Joule pulse energy laser modified surfaces $\left(51 \pm 3^{\circ}\right)$, values that were very close together. On the electropolished surfaces these were measured with the lowest values $\left(27 \pm 4^{\circ}\right)$, while the highest contact-angle values $\left(102 \pm 4^{\circ}\right)$ appeared on the 3 Joule impulse-energy laser modified surfaces. Quantitative and qualitative cell-test characterizations of the surfaces were made. In the case of tests with fibroblasts the greatest degree of cell proliferation was the surfaces sandblasted with $\mathrm{Al}_{2} \mathrm{O}_{3}$ particles. With the osteoblast tests the highest levels of cell activity were for the two types of laser-modified surface.

\section{References}

[1] Zhe, Q., Xiaohui, R. F., Marco, W., Michael, M., Andreas, S.: The Initial Attachment and Subsequent Behavior Regulation of Osteoblasts by Dental 
Implant Surface Modification. Journal of Biomedical Materials Research Part A, 82 (2007:3) 658-668

[2] Albrektsson, T., Brånemark, P. I., Hansson, H. A., Lindström, J.: Osseointegrated Titanium Implants. Acta Orthop Scand, 52 (1981) 155-170

[3] Kieswetter, K., Schwartz, Z., Dean, D. D., Boyan, B. D.: The Role of Implant Surface Characteristics in the Healing of Bone. Crit Rev Oral Biol Med, 7 (1996:4) 329-345

[4] Stadlinger, B., Korn, P., Tödtmann, N., Eckelt, U., Range, U., Bürki, A., Ferguson, S. J., Kramer, I., Kautz, A., Schnabelrauch, M., Kneissel, M., Schlottig, F.: Osseointegration of Biochemically Modified Implants in an Osteoporosis Rodent Model. Eur Cell Mater. 25 (2013:8) 326-40

[5] Cochran, D. L., Buser, D., ten Bruggenkate, C. M., Weingart, D., Taylor, T. M., Bernard, J. P., Peters, F., Simpson, J. P.: The Use of Reduced Healing Times on ITI Implants with a Sandblasted and Acid-etched (SLA) Surface: Early Results from Clinical Trialson ITI SLA Implants. Clinical Oral Implants Research, 13 (2002) 144-153

[6] Ramazanoglu, M., Oshida, Y.: Osseointegration and Bioscience of Implant Surfaces - Current Concepts at Bone-Implant Interface, Implant Dentistry A Rapidly Evolving Practice, Prof. Ilser Turkyilmaz (Ed.), Open Access Publisher: InTech, 2011

[7] Guéhennec, L. L., Soueidan, A., Layrolle, P., Amouriq, Y.: Surface Treatments of Titanium Dental Implants for Rapid Osseointegration. Dental Materials, 23 (2007) 844-854

[8] Puleo, D. A., Nanci, A.: Understanding and Controlling the Bone-Implant Interface. Biomaterials, 20 (1999) 2311-2321

[9] Hulbert, S. F., Morisson, S. F., Klawitter, J. J.: Tissue Reaction to Three Ceramics of Porous and Non-Porous Structures. J Biomed Mater Res 6 (1972) 347-374

[10] Carlsson, L., Rostlund, T., Albrektsson, T.: Removal Torque for Polished and Rough Titanium Implants. Int J Oral Maxillofacial Implants, 3 (1988) $21-22$

[11] Cochran, D. L.: A Comparison of Endosseus Dental Implant Surface. J Periodontal, 70 (1999) 1523- 1539

[12] De Assis, A. F., Beloti, M. M., Crippa, E. G., Oliveira, P. T., Morra, M., Roza, A. L.: Development of the Osteoblastic Phenothype in Human Alveolar Bone-derived Cells Grown on a Collagen Type I-coated Titanium Surface. Clin Oral Impl Res, 20 (2009) 240-246

[13] Wennerberg, A., Albrektsson, T., Andersson, B.: Design and Surface Characteristics of 13 Commercially Available Oral Implant Systems. Int J Oral Maxillofacial Implants, 8 (1993) 622-633 
[14] Wennerberg, A., Ektassobi, A., Albrektsson, T., Johansson, L., Andersson, B.: A 1-Year Follow up of Implants of Differing Surface Roughness Placed in Rabbit Bone. Int J Oral Maxillofac Implants, 12 (1997) 486-490

[15] Suba, Cs., Lakatos-Varsányi, M., Miko, A., Kovács, L., Velich, N., Kádár, B., Szabó, Gy.: Study of the Electrochemical Behaviour of Ti Osteosynthesis Plates Used in Maxillofacial Surgery. Mater Sci Eng, 447 (2007) 347-354

[16] Junker, R., Dimakis, A., Thoneick, M., Jansen, J. A.: Effect of Implant Surface Coatings and Composition on Bone Integration: a Systematic Review. Clin Oral Impl Res, 20 (2009) 185-206

[17] Kasemo, B., Gold, J.: Implant Surface and Interface Processes. Adv Dent Res, 13 (1999) 8-20

[18] Schwarz, F., Herten, M., Sager, M., Wieland, M., Dard, M., Becker, J.: Bone Regeneration in Dehiscence-Type Defects at Chemically Modified (SLActive) and Conventional SLA Titanium Implants: a Pilot Study in Dogs. J Clin Periodontol, 34 (2007) 78-86

[19] Velich, N., Kádár, B., Kiss, G., Kovács, K., Réti, F., Szigeti, K., Garagiola, U., Szabó, Gy.: Effect of Human Organism on the Oxide Layer Formed on Titanium Osteosynthesis Plates: A Surface Analytical Study. The Journal of Craniofacial Surgery, 6 (2006) 13-17

[20] Buser, D., Broggini, N., Wieland, M., Schenk, R. K., Denzer, A. J., Cochran, D. L., Hoffmann, B., Lussi, A., Steinemann, S. G.: Enhanced Bone Apposition to a Chemically Modified SLA Titanium Surface. J Dent Res, 7 (2004) 529-533

[21] Joób, F. Á., Huszár, T., Divinyi, T., Rosivall, L., Szabó, Gy.: The Effect of the Surface Mikromorphology of Titanium Implants on the Fibro- and Osteoblast Prolifeartion Activity. Fogorvosi Szemle, 97 (2004) 251-255

[22] Shibli, J. A., Grassi, S., de Figueiredo, L. C., Feres, M., Marcantonio, E. Jr.. Iezzi, G., Piattelli, A.: Influence of Implant Surface Topography on Early Osseointegration: a Histological Study in Human Jaws. Journal of biomedical materials research. Part B, Applied biomaterials, 80 (2007) 377385

[23] Soskolne, W. A., Cohen, S., Sennerby, L., Wennerberg, A, Shapira, L.: The Effect Oftitanium Surface Roughness on the Adhesion of Monocytes and their Secretion ofTNF-Alpha and PGE2. Clinical Oral Implants Research, 13 (2002) 86-93

[24] Klokkevold, P. R., Nishimura, R. D.: Osseointegration Enhanced by Chemical Etching of Titanium Surface. Clin Oral Impl Res, 8 (1997) 442447 
[25] Schwarz, F., Herten, M., Sager, M., Wieland, M., Dard, M., Becker, J.: Bone Regeneration in Dehiscence-Type Defects at Chemically Modified (SLActive) and Conventional SLA Titanium Implants: a Pilot Study in Dogs. J Clin Periodontol, 34 (2007) 78-86

[26] Orsini, G., Assenza, B., Scarano, A., Piatteli, M., Piatteli, A.: Surface Analysis of Machined versus Sandblasted and Acid-etched Titanium Implants. Int J Oral Maxillofac Implants, 15 (2000) 779-784

[27] Joób, F. A., Huszár, T., Divinyi, T., Rosivall, L.: The Effect of The Surface Micromorphology of Titanium Dental Implants on Proliferation Activity of Fibro-Osteoblasts. Paper presented at the 9. Kongress Der Österreichischen Gesellschaft Für Mund-, Kiefer-Und Gesichtschirurgie, Bad Hofgastein, Austria, 2005

[28] Yoshiki O.: Bioscience and Bioengineering of Titanium Materials. Second edition. Oxford: Elsevier, 2013

[29] Gaggl, A., Schultes, G., Müller, W. D., Karchen, M.: Scanning Electron Microscopical Analysis of Laser-treated Titanium Implant Surfaces - a comparative study. Biomaterials, 21 (2000) 1067-1073

[30] Nentwig, G. H., Reichel, M.: Vergleichende Untersuchung zur Mikromorphologie und Gesamtoberfläche enossaler Implantate Z. Zahnärztl Implantologie, 10 (1994) 150-154

[31] Wennerberg, A., Albrektsson, T., Ulrich, H., Krol, J. J.: An Optical ThreeDimensional Technique for Topographical Descriptions of Surgical Implants. Journal of Biomedical Engineering, 14 (1992) 412-418

[32] Wennerberg, A., Albrektsson, T., Andersson, B.: Design and Surface Characteristics of 13 Commercially Available Oral Implant Systems. Int J Oral Maxillofacial Implants, 8 (1993) 622-633

[33] Wennerberg, A., Albrektsson, T.: Bone Tissue Response to Commercially Pure Titanium Implants Blasted with Fine and Coarse Particles of Aluminium Oxide. Int J Oral Maxillofacial Implants, 11 (1996) 38-45

[34] Albrektsson, T., Wennerberg, A.: Die klinische Bedeutung verschidener Oberflacheneigenschafften enossaler. Titanimplantate Implantologie, 3 (1999) 235-246

[35] Wennerberg, A., Albrektsson, T.: Suggested Guidlines for the Topographic Evaluation of Implant Surfaces. Int J Oral Maxillofacial Implants, 15 (2000) 331-334

[36] Lazzara, R. J., Testori, T., Trisi, P., Porter, S. S., Weinstein, R. L.: A Human Histologic Analysis of Osseotite and Machined Surface using Implants with 2 Opposing Surfaces. Int J of Periodontics Restorative Dent, 19 (1999) 117-129 
[37] Ivanov, C. J., Hallgren, C., Widmark, G., Sennerby, L., Wennerberg, A.: Histologic Evaluation of the Bone Integration of $\mathrm{TiO} 2$ Blasted and Turned Titanium Microimplants in Humans. Clin Oral Impl Res, 12 (2001) 44-50

[38] Buser, D.: Titanimplantate mit angerauhter Oberfläche. Implantologie, 3 (1999) 249-268

[39] Piatteli, A., Corigliano, M., Scarano, A., Quaranta, M.: Bone Reactions to Early Occlusal Loading of Two Stage Titanium Plasma-sprayed Implants: a Pilot Study in Monkeys. Int J Periodontics Restorative Dent, 17 (1997) 162-169

[40] Hansson, S., Norton, M.: The Relation between Surface Roughness and Interfacial Shear Strength for Bone-anchored Implants. A Mathematical Model. J Biomech, 32 (1999) 829-36

[41] Miyamoto, I., Tsuboi, Y., Wada, E., Suwa, H., Iizuka, T.: Influence of Cortical Bone Thickness and Implant Length on Implant Stability at the Time of Surgery-Clinical. Prospective, Biomechanical, and Imaging Study, 37 (2005) 776-780

[42] Xianshuai, C., Longhan, X., Jianyu, C. R., Feilong, D.: Design and Fabrication of Custom-made Dental Implants. Journal of Mechanical Science and Technology, 26 (2012:7) 1993-1998

[43] Juodzbalys, G., Sapragoniene, M., Wennerberg, A., Baltrukonis, T.: Titanium Dental Implant Surface Micromorphology Optimization. Journal of Oral Implantology, 34 (2007:4) 177-85

[44] Park, J. Y., Davies, J. E.: Red Blood Cell and Platelet Interactions with Titanium Implant Surfaces. Clinical Oral Implants Research, 12 (2000) 530-539

[45] Pammer, D., Schindler, Á., Bognár, E.: Chemical Etching of Dental Implants. Gépészeti szám, 60 (2013) 29-32

[46] Rosa, A. L., Beloti, M. M.: Rat Bone Marrow Cell Response to Titanium and Titanium Alloy with Different Surface Roughness. Clinical Oral Implants Research, 14 (2003:1) 43-48

[47] Galli, C., Guizzardi, S., Passeri, G., Martini, D., Tinti, A., Mauro, G., Macaluso, G. M.: Comparison of Human Mandibular Osteoblasts Grown on Two Commercially Available Titanium Implant Surfaces. Journal of Periodontology, 76 (2005) 364-372

[48] Engquist, B., Astrand, P., Dahlgren, S., Engquist, E., Feldmann, H., Grondahl, K.: Marginal Bone Reaction to Oral Implants: a Prospective Comparative Study of AstraTech and Branemark System Implants. Clinical Oral Implants Research, 13 (2002) 30-37 
[49] Gaggl, A., Schultes, G., Muller, W. D., Karcher, H.: Scanning Electron Microscopic Analysis of Laser-treated Titanium Implant Surfaces -- a Comparative Study. Biomaterials, 21 (2000) 1067-1073

[50] Yamagami, A., Yoshihara, Y., Suwa, F.: Mechanical and Histologic Examination of Titanium Alloy Material Treated by Sandblasting and Anodic Oxidization. The International Journal of Oral Maxillofacial Implants, 20 (2005:1) 48-53

[51] Anil, S., Anand, P. S., Alghamdi, H., Jansen, J. A.: Dental Implant Surface Enhancement and Osseointegration. Implant Dentistry - A Rapidly Evolving Practice, Prof. Ilser Turkyilmaz (Ed.), Open Access Publisher: InTech, 2011

[52] Lill, W., Velikogne, W., Danhel-Mayrhauser, M., Haider, R., Plenk, H., Watzek, G.: Histomorphometrische untersuchung der Knochenreaktion um extraoralen Brånemark ${ }^{\circledR}$ - und TPS® Titanschrauben beim Schaf Zeitschrift für Zahnärzliche. Implantologie, 8 (1992) 103-112

[53] Uitto, V. J., Larjava, H., Peltonen, J., Brunette, D. M.: Expressions of Fibronectin and Integrins in Cultured Periodontal Ligament Epithelial Cells. J. Dent. Res., 71 (1997) 1203-1211

[54] Ericsson, I., Johansson, C. B., Bystedt, H., Norton, M. R.: A Histomorphometric Evaluation of Bone-to-Implant Contact on Machineprepared and roughened Titanium Dental Implants. Clin Oral Impl Res, 5 (1994) 202-206

[55] Wennerberg, A., Ektassobi, A., Albrektsson, T., Johansson, L., Andersson, B.: A 1- Year Follow up of Implants of Differing Surface Roughness Placed in Rabbit Bone. Int J Oral Maxillofac. Implants, 12 (1997) 486-490

[56] Cordioli, G., Piatteli, A.: Removal Torque and Histomorphometric Investigation of 4 Different Titanium Surface: an Experimental Study in the Rabbit Tibia. Int J Oral and Maxillofacial Implants, 15 (2000) 668-674

[57] Baker, D. A., London, R. M., Oneal, R. B.: Integration Strength and Speed of Dual-etched Titanium Implants: A Comparative Study in Rabbits. $13^{\text {th }}$ Annual Meeting, Academy of Osseointegratio, Atlanta, Georgia, 1998

[58] Trisi, P., Lazzara, R., Rao, W., Reboudi, A.: Bone-Implant Contact and Bone Quality: of Expected and Actual Bone Contact on Machined and Osseotite Implant Surface. Int J Periodontics Rest Dent, 22 (2002) 535-545

[59] Wennerberg, A., Hallgren, C., Johansson, C., Danelli, S.: A Histomophometric Evaluation of Screw-shaped Implants Each Prepared with Two Surface Rougness. Clin Oral Impl Res, 9 (1998) 11-19

[60] Buser, D., Schenk, R. K., Steinemann, S., Fiorellini, J. P., Fox, C. H., Stich, H.: Influence of Surface Characteristics on Bone Integration of Titanium 
Implants. A Histomorphometric Study in Miniature Pigs. J Biomed Mater Res, 25 (1991) 889-902

[61] Christenson, E. M., Anseth, K. S., van den Beucken, J. J., Chan, C. K., Ercan, B., Jansen, J. A., Laurencin, C. T., Li, W. J., Murugan, R., Nair, L. S., Ramakrishna, S., Tuan, R. S., Webster, T. J., Mikos, A. G.: Nanobiomaterial Applications in Orthopedics. J Orthop Res, 25 (2007) 1122

[62] Carlos, N. E., Yoshiki, O., José, H. C. L., Carlos, A. M.: Relationship between Surface Properties (Roughness, Wettability and Morphology) of Titanium and Dental Implant Removal Torque. Journal of the Mechanical Behavior of Biomedical Materials, 1 (2008:3) 234-242

[63] Luiz, M.: On Nano Size Structures for Enhanced Early Bone Formation. PhD-dissertation, Inst of Odontology. Dept of Prosthetic Dentistry, Dental Material Science, Göteborg University, Göteborg, Sweden, 2007

[64] Frauchiger, V. M.: Anodic Plasma-Chemical Treatment of Titanium Implant Surfaces. PhD-dissertation, Technische Wissenschaften ETH Zürich, Zürich, Switzerland, 2002

[65] Göransson, A.: On Possibly Bioactive CP Titanium Implant Surfaces. PhDdissertation, Department of Prosthetic Dentistry, University of Gothenburg, Göteborg, Sweden, 2009

[66] Ogiso, M., Yamamura, M., Kuo, P. T., Borgese, D., Matsumoto, T.: Comperative Push-Out Test of Dense HA Implants and HA-coated Implants: Findings in a Canine Study. J. Biomed. Mater. Res, 39 (1998) 364-372

[67] Svehla, M., Morberg, P., Zicat, B., Bruce, W., Sonnabend, D., Walsh, W. R.: Morphometric and Mechanical Evaluation of Titanium Implant Integration: Comparison of Five Surface Structures. J. Biomed. Mater. Res., 51 (2000) 15-22

[68] Sennersby, L., Thomsen, P., Ericson, L. E.: A Morphometric and Biomechanic Comparison of Titanium Implants Inserted in Rabbit Cortical and Cancellous Bone. Int J Oral Maxillofac Implants, 7 (1992) 62-71

[69] Cordioli, G., Piatteli, A.: Removal Torque and Histomorphometric Investigation of 4 Different Titanium Surface: an Experimental Study in the Rabbit Tibia. Int J Oral and Maxillofacial Implants, 15 (2000) 668-674 